\title{
ROUGHING IT IN THE BUSH, THE GRAPHIC NOVEL
}

\author{
Javier Martín Párraga \\ Universidad de Córdoba
}

\begin{abstract}
Graphic novels and comic books are no longer minor cultural artifacts which are produced to generate economic benefits, mostly consumed by young, not very literate, readers who do not hope to be educated but simply entertained. Quite on the contrary, authors such as Will Eisner, Art Spiegelman, Alan Moore, Neil Gaiman or Umberto Eco has vindicated the fundamental role these artistic manifestations play nowadays. The present paper analyzes Carol Shields and Patrick Crowe 2016 graphic novel adaptation of Susanna Moodie's seminal book Roughing it in the Bush. In order to reach this goal, a brief theoretical state of the art is introduced. Consequently, the original writer and text are equally studied. Finally, the contemporary graphic novel adaptation is considered, explaining the genesis of the project as well and the similitudes and differences it shows when compared to the original work by Susanna Moodie.
\end{abstract}

Keywords: Canadian Literature, Susanna Moodie, Graphic Novels, Margaret Atwood.

\section{ROUGHING IT IN THE BUSH, LA NOVELA GRÁFICA}

\section{RESUMEN}

Las novelas gráficas no se consideran ya como artefactos culturales de valor menor que se producen principalmente en pos de intereses comerciales y son consumidas por lectores jóvenes y, por lo general poco formados que buscan deleitarse, pero no instruirse con estas lecturas. Muy al contrario, autores de la talla de Will Eisner, Art Spiegelman, Alan Moore, Neil Gaiman o Umberto Eco han reivindicado el papel fundamental que estas manifestaciones artísticas desempeñan a día de hoy. El presente artículo examina la adaptación gráfica que en 2016 llevaron a cabo Carol Shields y Patrick Crowe de la seminal obra de Susanna Moodie, Roughing it in the Bush. Para alcanzar este objetivo, ofrerecemos un sucinto estado de la cuestión téorico. Asimismo, se presentarán a la autora y texto originales. Por último, estudiaremos en profundidad la novela gráfica, explicando su génesis, así como las diferencias y semejanzas que presenta con respecto a la obra original que Susanna Moodie diera a la imprenta.

Palabras Clave: literatura canadiense, Susanna Moodie, novelas gráficas, Margaret Atwood.

DOI: https://doi.org/10.25145/j.recaesin.2020.81.21

Revista Canaria de Estudios Ingleses, 81; November 2020, pp. 321-334; ISSN: e-2530-8335 


\section{POSTMODERNITY AND GRAPHIC NOVELS}

Up to the twentieth century, there seemed to be many more certainties than doubts in virtually every scientific, social and cultural realm. Scientific laboratories did not stop making advances at an escalating rate and humanity seemed determined to reach levels of technical expertise that would make our future lives longer, healthier and happier. Nevertheless, during the second half of the century though our technical skill would have allowed us to reach an Edenic scenario we used it instead to deploy two devastating atomic bombs and the allies' efforts to destroy the evil Nazi axis required them to become mass-murderers like Stalin or Machiavellian as Churchill and Truman. In this particular scenario, Adorno raised the famous question of whether it was still legitimate to make poetry and pretty soon thinkers like Derrida, Lyotard, Foucault or Baudrillard concentrated on deconstructing any previous certainty we might have naïvely enjoyed in the past.

Needless to say, the radical frames of thought that demolished traditional comforting moral binary opposites were also destined to affect our traditional understanding of the arts. Thus, contemporary readers were forced to reconsider the extent to which a canon was possible and also whether the idea of genre was valid in a time in which, as Schrödinger proved, cats could be simultaneously living and dead. In other words, the barrier between high and pop art cracked and canonical texts that were not supposed to be treated frivolously were deprived of all their longlasting scholarly traditional armor. Thus, John Barth rewrote many foundational American myths (like that of Pocahontas) and Donald Barthelme did the very same with some passages from the Iliad, just to mention some quintessential examples.

Together with the new postmodern frame of mind, the twentieth century was characterized by global literacy in a Western world in which it became less and less frequent to have the opportunity to enjoy time in a domestic, familiar environment. Consequently, new means of communication and entertainment like TV, "glossy magazines", pulp fiction and comic books flourished, trying to satisfy the demands of an increasingly high number of teenagers and young adults that had free time but lacked the company of their parents, who devoted more and more time to work in a capitalistic (sometimes cannibalistic) scenario that placed their safe suburban homes far away from their work places.

If we combine a playful philosophy that invited authors and readers to question the very nature of the Western canon and fostered collages and "mutant ways of artistic creation" with a huge mass of consumers that showed themselves to be hungry for escapist fiction, it is no surprise to discover that the second half of the twentieth century was full of science fiction, soap operas, detective stories and superheroes. These new cultural icons populated the bookshelves of libraries, bookshops and airports' and train stations' convenience stores.

At this point, we might wonder what place ancient cultural artefacts play in this novel and radical world. First of all, old-fashioned moral certainties and the great artistic pieces of the traditional past did not prevent the human race from committing the atrocities of Auschwitz, Hiroshima and Dresden, of the on-going massacres of a Cold War that was absolutely hot if you had the bad luck to live in 
But there were

thousands upon thousands of orther people inthe city who bought bad chemicals and ate them or sniffed them-or injected them into their veins with devices which looked like this:

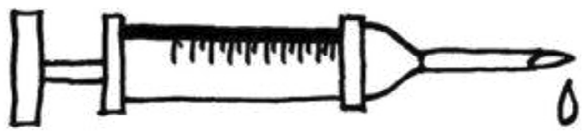

Sometime they even stuffed bad chemicals up their assholes. Their assholes looked like this:

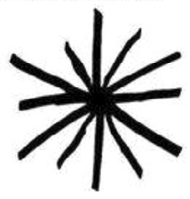

Figure 1. Example from Vonnegut's Breakfast. of Champions.

the Balkans or Indochina, just to name two places. Thus, many postmodern artists rejected the certainties of orthodox art and dived deeply into the remote past or hidden areas of the mind. In search of a purer, less contaminated age, these artists journeyed far away, arriving at places that existed prior to our technological splendor and the simplistic Judeo-Christian sets of values and beliefs that led us to two World Wars and the ominous shadow of an atomic (and inherently apocalyptic) third one that seemed to be eternally waiting to be unleashed. Thus, prehistoric and aboriginal art (by definition impossible to be reduced to black and white interpretations) was rediscovered and reinterpreted.

It becomes necessary to point out that the entertainment industry, located basically in the UK and the USA, was influenced, if not driven, by extremely conservative forces. Thus, science fiction, fantasy texts and comic books would not be allowed to share the extremely radical attitude that was embraced by the writers of novels who on many occasions were not university professors but underground individuals who didn't need any sort or financial support or social recognition. Traditionally, folktales had played a crucial role in transmitting and consolidating values and attitudes that were fundamental to society. Consequently, in this new scenario, with new aesthetic preferences and very few moments in the company of the family, the docere et delectare functions should be fulfilled by new artistic and cultural manifestations.

Taking this socio-cultural context into account, it is not surprising that graphic novels stopped being considered as minor literary elements and began to be praised by intellectuals and scholars. Very clear examples of prestigious scholars and writers who didn't hesitate to defend graphic novels and comic books as artistic creations are that of Umberto Eco and Kurt Vonnegut.

In 1973, Vonnegut sent to the press the novel Brekafast of Champions, in which graphic elements did not only illustrate or accompany the novel but became indispensable elements of the plot, as the Figure 1 shows. 
In the case of Umberto Eco, this brilliant intellectual did not only vindicate the ninth art but also contributed to it with his fascinating work The Mysterious Flame of Queen Loana: an Illustrated Novel (2004). Thus, Will Eisner's, Alan Moore's or Neil Gaiman's complex, exciting and extremely rich works gained critical reputation at the same time they entertained and educated millions of young readers. An even more exemplary case is that of Art Spiegelman's masterly graphic novel on the holocaust, Maus, which received the Pulitzer Award in 1992.

\section{SUSANNA MOODIE'S ROUGHING IT IN THE BUSH: THE SOURCE TEXT}

Susanna Strickland Moodie (1803) arrived to Canada in 1832, escaping from an economic situation in England that was starting to be quite difficult at that moment and would become even harder in the near future when Moodie's first son was born. She was the sixth daughter of Thomas and Elizabeth Homer Strickland, a well-read family that soon gained reputation within British literary circles.While in England, Susanna Moodie had already published some poetry books as well as children literature, but her fame as a writer is mostly due to the book Roughing it in the Bush (1852), in which she chronicles her first years as a settler in Upper Canada.In the introduction to Roughing it in the Bush, Susanna Moodie reflects upon the reasons why emigrants chose Canada as their destination, which were, in fact, mythical:

The choice of the country to which they devote their talents and energies depends less upon their pecuniary means than upon the fancy of the emigrant or the popularity of a name. From the year 1826 to 1829 , Australia and the Swan River were all the rage. No other portions of the habitable globe were deemed worthy of notice. These were the El Dorados and lands of Goshen to which all respectable emigrants eagerly flocked. Disappointment, as a matter of course, followed their high-raised expectations. Many of the most sanguine of these adventurers returned to their native shores in a worse condition than when they left them. In 1830, the great tide of emigration flowed westward. Canada became the great land-mark for the rich in hope and poor in purse. Public newspapers and private letters teemed with the unheard-of advantages to be derived from a settlement in this highlyfavored region. ${ }^{1}$

Nonetheless, reality soon proves those unreal expectations false, reducing many of those fanciful colonists to a state of absolute poverty and desolation:

Oh, ye dealers in wild lands-ye speculators in the folly and credulity of your fellow men-what a mass of misery, and of misrepresentation productive of that misery, have ye not to answer for! You had your acres to sell, and what to you were the

${ }^{1}$ All quotations from Moodie's Roughing in the Bush has been retrieved from: https://digital. library.upenn.edu/women/moodie/roughing/roughing.html. 
worn-down frames and broken hearts of the infatuated purchasers? The public believed the plausible statements you made with such earnestness, and men of all grades rushed to hear your hired orators declaim upon the blessings to be obtained by the clearers of the wilderness.

Men who had been hopeless of supporting their families in comfort and independence at home, thought that they had only to come out to Canada to make their fortunes; almost even to realize the story told in the nursery, of the sheep and oxen that ran about the streets, ready roasted, and with knives and forks upon their backs. They were made to believe that if it did not actually rain gold, that precious metal could be obtained, as is now stated of California and Australia, by stooping to pick it up.

When the myth of a paradise on Earth where richness rained from the sky on a regular basis is subverted by harsh realities; two new foundational myths are attached to Canada: that of the American dream and the mythical spirit of the frontier hero:

The Great Father of the souls and bodies of men knows the arm which wholesome labour from infancy has made strong, the nerves which have become iron by patient endurance, by exposure to weather, coarse fare, and rude shelter; and he chooses such, to send forth into the forest to hew out the rough paths for the advance of civilization. These men become wealthy and prosperous, and form the bones and sinews of a great and rising country. Their labor is wealth, not exhaustion; its produce independence and content, not home-sickness and despair.

During her sojourn in Canada's backwoods, Moodie is faced with numberless difficulties and sorrows and she is often haunted by a debilitating melancholy. Thus, several passages from Roughing it in the Bush present us with a Moodie which dreams with returning to a land which is no longer real but idealized, in this case by the myth of the Common Wealth as a beacon of civilization, prosperity and happiness. But, at those moments of doubts and sorrow when nostalgia overwhelms the author, the sublime, mythical, beauty of Canadian landscape re comforts her, as the following stanza from the poem "Canada" shows:

By thy winter's stainless snow,

Starry heavens of purer glow,

Glorious summers, fervid, bright,

Basking in one blaze of light;

By thy fair, salubrious clime;

By thy scenery sublime;

By thy mountains, streams, and woods;

By thy everlasting floods;

If greatness dwells beneath the skies,

Thou to greatness shalt arise!

And, step by step, the idealized sublimity of Canadian nature becomes productive of political and personal independence: 
Canadians! -as long as you remain true to yourselves and her, what foreign invader could ever dare to plant a hostile flag upon that rock-defended height, or set his foot upon a fortress rendered impregnable by the hand of Nature? United in friendship, loyalty, and love, what wonders may you not achieve? to what an enormous altitude of wealth and importance may you not arrive? Look at the St. Lawrence, that king of streams, that great artery flowing from the heart of the world, through the length and breadth of the land, carrying wealth and fertility in its course, and transporting from town to town along its beautiful shores the riches and produce of a thousand distant climes. What elements of future greatness and prosperity encircle you on every side! Never yield up these solid advantages to become an humble dependent on the great republic-wait patiently, loyally, lovingly, upon the illustrious parent from whom you sprang, and by whom you have been fostered into life and political importance; in the fullness of time she will proclaim your childhood past, and bid you stand up in your own strength, a free Canadian people!

Another important myth that needs to be considered in Roughing it in the Bush is related to Moodie's Indian neighbors. The author's depiction of the local inhabitants shares features both from the myth of the noble savage and from Hobbes' nihilistic understanding of the human soul:

It was not long before we received visits from the Indians, a people whose beauty, talents, and good qualities have been somewhat overrated, and invested with a poetical interest which they scarcely deserve. Their honesty and love of truth are the finest traits in characters otherwise dark and unlovely. But these are two God-like attributes, and from them spring all that is generous and ennobling about them. There never was a people more sensible of kindness, or more grateful for any little act of benevolence exercised towards them. We met them with confidence; our dealings with them were conducted with the strictest integrity; and they became attached to our persons, and in no single instance ever destroyed the good opinion we entertained of them.

The men of this tribe are generally small of stature, with very coarse and repulsive features. The forehead is low and retreating, the observing faculties large, the intellectual ones scarcely developed; the ears large, and standing off from the face; the eyes looking towards the temples, keen, snake-like, and far apart; the cheek-bones prominent; the nose long and flat, the nostrils very round; the jawbone projecting, massy, and brutal; the mouth expressing ferocity and sullen determination; the teeth large, even, and dazzlingly white. The mouth of the female differs widely in expression from that of the male; the lips are fuller, the jaw less projecting, and the smile is simple and agreeable. The women are a merry, lighthearted set, and their constant laugh and incessant prattle form a strange contrast to the iron taciturnity of their grim lords.

To conclude with Susanna Moodie's original Roughing it in the Bush; the book started as a diaspora narrative in which the author felt exiled not only from her mother land but also from civilization and thrown into the barbaric shores of a country where nature and not sociey prevailed and conditioned the lives and destinies of the settlers. This creates a shock and Moodie is overwhelmed by loneliness, fear and even desperation. Nonetheless, in this book nature enables Moodie to be 
transformed. By the end of the volumes, she is no longer an exiled British lady but a true, proud, Canadian. She is finally living the myth of the American dream and enjoying freedom and prosperity for her and her sons and daughters. The book closes with a poem, "A Canadian Son" in which it becomes clear that the abovementioned transformation was only made possible by Canada's nature, which is simultaneously real and mythical:

\author{
Hail to the pride of the forest-hail \\ To the maple, tall and green; \\ It yields a treasure which ne'er shall fail \\ While leaves on its boughs are seen. \\ When the moon shines bright, \\ On the wintry night, \\ And silvers the frozen snow; \\ And echo dwells \\ On the jingling bells \\ As the sleighs dart to and fro; \\ Then it brightens the mirth \\ Of the social hearth \\ With its red and cheery glow.
}

\title{
3. MARGARET ATWOOD'S INTRODUCTION TO ROUGHING IT IN THE BUSH, THE GRAPHIC NOVEL
}

Canadian publishing house Second Story Press, supported by several public agencies such as Ontario Arts Council; Ontario Media Developing Corporation and Carol Shields Literary Trust published the graphic novel adaptation of Roughing it in the Bush in 2016. The books opens with an introduction by Margaret Atwood (b. 1939), one of Canada's most prestigious and prominent scholars and writers. Atwood is not only the most awarded and best-known Canadian woman writer but also a true expert in Susanna Moodie and Roughing it in the Bush.

In 1970, A young Margaret Atwood published The Journals of Susanna Moodie, in which she puts herself in the shoes of pioneer woman writer Susanna Strickland Moodie, who arrived to Canada in 1832 and narrated her experiences as a settler in her seminal works Rouging it in the Bush (1852) and Life in the Clearings versus the Bush (1853). Atwood's fascination with Moodie and her chronicles are natural and inevitable. First of all, as a feminist young author searching for literary influences, Atwood couldn't find an earlier or more powerful example of a Canadian woman who was free, strong and foundational for Canadian literature. In March 1995, Victor-Lévy Beaulieu spent a week in Toronto with Atwood. Their lengthy and extremely interesting conversations were published the following year. Creating a postmodern game of matriuska dolls, the title of this book echoes Hugh MacLennan's novel, which echoes Rene Marie Rilke's poem: Two Solitudes. In this book, Atwood remembers how little contact with Canadian literature she had while at college: 
I started university in 1957, in English literature. We didn't learn much Canadian literature, or even much American literature. We started with Anglo-Saxon, and went on to Chaucer, and then to Shakespeare. And finally we got to the twentieth century and we studied a little Hemingway and Faulkner. I enjoyed it (31).

Obviously, the relation between these two Canadian women writers is complex and concepts such as the anxiety of influence or negative influence must be taken into account.

But Atwood could project her own quest for identity in Moodie not only because of Moodie's role as a literary mother.

As Rosemary Sullivan states: "the landscape of childhood provides the foundation layer of our psyche. Margaret's landscape was the north woods" (29). In Two Solitudes readers do discover the background of Atwood's childhood and the author herself confirms Sullivan's hypothesis, as the following set of quotations prove: "when we were little, we spent most of the year very isolated [...] in our house all alone in the woods" (9); "there were also a few Indians" (11); "our house was very isolated, and the lake was very big" (sp); "I spent a few months in school. Up to the age of twelve, I did only one complete school year, because we were in the bush" (19). Even when Atwood was born almost a century after Moodie experienced her Canadian life, the scenes described by Atwood above are more similar than different to Moodie's existence in the isolated scenario of Canadian backwoods.

As we see, it is not surprising at all that Atwood did choose Moodie's seminal examination of the origins of Canada as a model for her own examination of both the country and her own psyche.

As a result of Atwood's intimate knowledge of the source text in which the graphic novel is inspired, her introduction becomes extremely interesting, at the same time it increases the graphic novel's artistic and cultural aspirations and relevance. In this introduction, Atwood starts by affirming that,

I am not only pleased but astonished to have been asked to welcome this graphic novel version into the world. If you've told me forty-five years ago that such a thing would happen, I would have thought you were fantasizing. And if you've told Mrs. Moodie herself, she'd have thought you were talking gibberish (vii).

This first idea is fundamental, since it proves to what extent our understanding of comic books and graphic novels have changed in quite a short span of time. It makes sense that in the nineteen century, Moodie could have thought that recreating her book as an illustrated story was an option which resulted equally absurd and impossible. But also in the seventies (a historical moment in which cultural revolutions were changing the world in such a fast and tremendous manner), an open-minded young woman poet would have thought the same.

Nonetheless, when writing this introduction in 2016 Atwood is an extremely prestigious 77 years-old artist and now the possibility of such a project does not only look feasible but also extremely enriching for the education of young Canadians: "I myself discovered Susanna Moodie on my parents' bookshelf in 1948, when I was eight $\{\ldots\}$ I was impressed. But the prose style of the book was too grown-up for 
me, so I abandoned it. Had there been a Classic Comic available, however, I would have read that" (vii-viii).

In the paragraph which closes her introduction, Atwood declares in an enthusiastic manner that this graphic novel won't only be positive for those young readers who get a first contact with the original text and her author, but also fundamental for the future reception of Susanna Moodie's literary canon, both within and outside academia:

This graphic version does justice to the many facets of her tale. It will introduce a new generation of readers to a figure that remains both iconic and - despite all the attention lavished upon her over the past forty-five years - mysterious. She may not be finished with us yet. What new Susanna Moodie may yet appear in years to come? (x).

\section{CAROL SHIELDS AND PATRICK CROWE: THE GENESIS OF THE GRAPHIC NOVEL ADAPTATION}

The two writers behind this graphic novel adaption of Susanna Moodie's Roughing it in the Bush are Carol Shields and Patrick Crowe. Shields (1935-2003) is one of the most influential Canadian writer of the twentieth century, having published plays, poems, essays and novels. Her literary efforts have been awarded with honors as prestigious as the Governor General's Award, the Orange Prize and even a Pulitzer Prize. Just as it happened with Margaret Atwood, Carol Shields' familiarity with Roughing it in the Bush is extreme, since she wrote her Master Thesis on this book and later published several essays about it. She is also the editor of one of the best scholarly editions of Roughing it in the Bush appeared so far. Patrick Crowe is not a writer but a film director and producer who first got in touch with Carol Shields in 1997, when he wrote, produced and directed a 50 minutes-long documentary on Moodie and her literary work, The Enduring Enigma of Susanna Moodie.

As Crowe himself explains in the Author's Note to the graphic novel, since 1997, he and Shields have wanted to work together on Moodie again. Their original idea was not to write a graphic novel adaptation of Roughing it in the Bush, but rather to co-write the screenplay for a feature film on Susanna Moodie. Nonetheless, the project proved to be more problematic than the authors had originally though. First of all, the very nature of the source material resulted very difficult to be transferred to the silver screen:

Carol felt very strongly that our goal was a psychological, not historical truth, and that all our choices needed to reinforce the best dramatic arc for a feature film. Simply by retelling Susanna’s own story (itself highly edited, even redacted) would not realize the potential of film to inspire the viewer's imagination (139).

As a result of Susanna Moodie's apparent resistance to become a film character, the first draft of the screenplay took four years to be completed. And by that moment, Shields' breast cancer did re-appear and spread. As a consequence, the film 
project was first delayed and finally cancelled. But in 2003, Patrick Crowe decided to resuscitate the enterprise, but this time, "not as a film but as a very cinematic graphic novel" (140). Then, with the inestimable financial support from the Canada Media Fund, Crowe got in touch with two young Canadian illustrators, Willow Dawson and Selena Goulding, who took care of the graphic part of this adaptation.

\section{DIFFERENCES AND SIMILITUDES BETWEEN THE NOVEL AND ITS GRAPHIC NOVEL ADAPTATION}

Once I have introduced the source text and dealt with the genesis of the graphic novel, it is time to consider the differences and similitudes between both versions. It becomes necessary to start by affirming that Shields' and Crowe's intimate knowledge of the original book and the author's biography and their firm commitment with the project do guarantee the quality and loyalty of the graphic novel to the book it is simultaneously adapting, updating and paying homage to.

Starting by the narratological voice, the graphic novel version is absolutely coherent with the one which was written more than one hundred years ago. Susanna Moodie wroteherself into Roughing it in the Bush in a sincere, honest and familiar manner (which is not surprising if we take into account both the biographical nature of the text and the fact that Barthes' theory of the death of the author was still far from appearing). Moodie understood his literary work as both a valid entertaining work and as a vehicle of social education (in this case it is impossible not to refer to Latin philosopher Horace's concept of prodesse et delectare which prevailed in English literature of the eighteenth and nineteenth centuries, before Modernism and Postmodernism made us question whether art could be educational at all). As a result, she made all the possible efforts to write her book in a way that grasped the readers' attention at the same time she hoped those same writers could identify with herself.

The graphic novel adopts a similar strategy at the same time, it remains faithful to Moodie's idiosyncratic prose. For instance, Shields and Crowe do not employ Canadian English but British one, since the Canadian variety had not evolved yet. As an example, on page: "My nearest neighbour in Africa was ten miles away" (9). As we see, British "neighbour" is employed here, rather than American and Canadian "neighbor". The graphic novel is loyal to Moodie's language and style even when the original version of the book crashes with the reader's contemporary decorum and political correctness. In order to prevent possible misunderstanding regarding this matter, on the credit page, the authors state the following,

Upper Canada in the 1830 s vibrated with a volatile mixture of many cultures, religious beliefs, and political views. Common prejudices in the nineteenth century resulting from antagonisms between Protestant and Catholics, or racism perpetrated by white Europeans against Blacks and Aboriginals, were reflected in the everyday language people used to describe themselves and each other. Today it is unacceptable to use words such as Indians, squaw, darkie, Negro, Yankee, or Papist. 
Use of such language in this book should be viewed in the context of its time in history.

The authors and publisher of this book do not condone the use of disrespectful language.

As well as being loyal to Moodie's voice, the authors of the graphic novel are equally faithful to the thematic elements from the original book. But, obviously, transferring a 500 pages long novel to a less than 130 pages graphic novel in which illustrations occupy a significant space necessarily imply the usage of several adaptation strategies. I will now examine the above-mentioned mechanisms.

The first change that is introduced in the graphic novel affects the structure and organization of the narrative. Roughing it in the Bush was published at a moment in which the canon of the novel as we know it nowadays was far from being established. As a result, Moodie's volume is characterized by a heterogeneous and fragmentary nature. The book is fragmentary because of the author's lack of experience as a novelist, because of the biographical nature of the work, due to the fact that she relies exclusively on her memory to transmit events that took places twenty years before and because before it appeared as a unified book, several passages from Roughing it had appeared previously in several British, Canadian and American journals and newspapers. And it is fragmentary because Susanna Moodie included not only prose, but also short poems and even drawings in the original version.

On the contrary, the graphic novel unifies the different materials and arrange them chronologically (often correcting mistakes Moodie has made), in order to offer contemporary readers a book which can be read in a swift and pleasant manner, without the burdens introduced by broken stories and disordered events which are inherent to heterogeneous and fragmentary texts from the past.

The second change that Shield and Crowe make in order to adapt Roughing it in the Bush to the demands of the graphic novel genre is related to Moodie's frequent digressions. In the original book, the plot is constantly being interrupted by the author's rambling and comments, which could be political, cultural, religious or even domestic ones. As a result, even when the book is, as a whole, exciting and interesting, we must accept the fact that it is not specially entertaining or easy to follow.

If digressions were acceptable (inevitable, I might say) during the nineteenth century, they are definitively incompatible with contemporary graphic novels. One could argue that Alan Moore's Watchmen, V. for Vendetta, From Hell or Neil Gaiman's The Sandman are full of philosophical remarks. That's absolutely true but, at the same time, both Moore and Gaiman are skilled graphic novel writers who know when, where and for how long those footnotes are to be introduced. In the case of the work I am analyzing in this case, Shields and Crowe did consider that Moodie's wanderings off the subject wouldn't fit the resulting graphic novel. And I cannot but agree with them. Consequently, the immense majority of digressions have been eluded.

The third difference between the source text and the contemporary one involves subplots. While Moodie's original work offered numberless subplots 
(which were not only fitting or interesting), Shields and Crowe have preferred to stick to the main plot in this case: Susanna Moodie's emigration to Canada and the many difficulties she and her family had to overcome in order to become wealthy Canadian citizens.

The final change that takes place in the graphic novel involves the final chapter. Susanna Moodie's book ended when the author and her family abandoned the backwoods of Canada, circa 1850, when the writer was 47 years old. The graphic novel, on the contrary imitates Margaret Atwood's The Journals of Susanna Moodie and introduce two new chapters, which did not appear in the original version.

The new two chapters are included in the section "Epilogues" and are called "Niagara!" and "The Bush Garden". The action in these original chapters takes place in 1867 and 1884, respectively, when Susanna Moodie is a mature lady who lives comfortably in Beleville town, far from the dangers, discomforts and quests she had to overcome in the remote and wild bush. In these new additions, Shields and Crowe include elements from Moodie's last years of life that were not included in Roughing it in the Bush but are widely known due to later works by the author (such as Life in the Clearings Versus the Bush,1853) and the letters of the author which were collected, edited and published by Carl Ballstadt, Elizabeth Hopkins, and Michael Peterman in 1985 (Letters of a Lifetime). 


\section{WORKS CITED}

Atwood, Margaret. The Journals of Susanna Moodie. Oxford University Press, 1970.

Bennett, Paul W. and Cornelius J. Jaenen. Emerging Identities: Selected Problems and Interpretations in Canadian History. Prentice-Hall Canada, 1986.

Bercuson, David Jay and J.L. Granatstein. The Collins Dictionary of Canadian History: 1867 to the Present. Collins, 1988.

Berger, Carl. The Writing of Canadian History: Aspects of English-Canadian Historical Writing, 19001970. Oxford University Press, 1976.

BuIss, John William Michael. Canadian History in Documents, 1763-1966. Ryerson Press, 1966.

Dahl, Edward H. Mid Forests Wild: A Study of the Concept of Wilderness in the Writings of Susanna Moodie, J.W.D. Moodie, Catherine Parr Traill and Samuel Strickland, C. 1830-1855. Mercury Series. National Museum of Man, Ottawa. National Museums of Canada, 1973.

Dawson, Willow, et al. Susanna Moodie: Roughing It in the Bush. Second Story Press, 2016.

Eco, Umberto, and Geoffrey Brock. The Mysterious Flame of Queen Loana: An Illustrated Novel. 1st ed. Harcourt, 2005.

Forkey, Neil Stevens. Canadians and the Natural Environment to the Twenty-First Century. Themes in Canadian History. University of Toronto Press, 2012.

Gray, Charlotte. Sisters in the Wilderness: The Lives of Susanna Moodie and Catharine Parr Traill. Viking, 1999.

Iacovetta, Franca, Paula Draper, and Robert Ventresca. A Nation of Immigrants: Women, Workers, and Communities in Canadian History, 1840s-1960s. University of Toronto Press, 1998.

Jefferys, Charles W. and W. Stewart Wallace. The Story of the Pioneers and How They Settled Canada. Imperial Oil Limited Portfolio. Imperial Oil Limited, 1965.

Moodie, Susanna, et al. Letters of a Lifetime. University of Toronto Press, 1985.

Moodie, Susanna, and Robert L. McDougall. Life in the Clearings: To Which Is Added This Author's Introduction to Mark Hurdlestone. Macmillan of Canada, 1976.

Moodie, Susanna, and Michael A. Peterman. Roughing It in the Bush: Authoritative Text, Backgrounds, Criticism. A Norton Critical Edition. W.W. Norton, 2007.

Moodie, Susanna, and John H. Thurston. Voyages: Short Narratives of Susanna Moodie. Canadian Short Story Library. University of Ottawa Press, 1991.

Morgan, Cecilia Louise. Commemorating Canada: History, Heritage, and Memory, 1850s-1990s. Themes in Canadian History. University of Toronto Press, 2016.

Muise, D.A., J.L. Granatstein, and Paul Douglas Stevens. A Reader's Guide to Canadian History. 2 vols. University of Toronto Press, 1982.

Palmer, Howard. Immigration and the Rise of Multiculturalism. Issues in Canadian History. Copp Clark Pub., 1975.

Peterman, Michael A. Susanna Moodie: A Life. ECW Press, 1999.

Peterman, Michael A. Sisters in Two Worlds: A Visual Biography of Susanna Moodie and Catharine Parr Traill. Doubleday Canada, 2007. 
Schindler, Karen, et al. Women Poets in Canadian History, 2007. Living Archives. Feminist Caucus of the League of Canadian Poets, 2008.

Shields, Carol. Susanna Moodie: Voice and Vision. Borealis Press, 1977.

Silver, A.I. and Carl Berger. An Introduction to Canadian History. Canadian Scholars' Press, 1991.

Vonnegut, Kurt. Breakfast of Champions; or, Goodbye Blue Monday! Delacorte Press, 1973.

Whalley, Peter, and John Robert Colombo. Great Moments in Canadian History. Hounslow Press, 1984. 